\title{
二酸化炭素の電気還元触媒の開発*
}

\section{Development of Electrocatalyst to Reduce Carbon Dioxide}

\author{
Masahiro FURUYA *1 \\ ${ }^{* 1}$ Central Research Institute of Electric Power Industry (CRIEPI) \\ 2-11-1 Iwado-kita, Komae, Tokyo 201-8511 Japan
}

\begin{abstract}
The carbon-doped copper oxide is devised as an electrocatalyst to reduce carbon dioxide under ambient pressure and temperature. The electrode was immersed into a $\mathrm{KHCO}_{3}$ aqueous solution with $\mathrm{CO}_{2}$ bubbling. The electric potential was maintained at $-1.64 \mathrm{~V} v s$ SHE. The electrode prepared at $900{ }^{\circ} \mathrm{C}$ gives the maximum production rate of ethylene (25\%), ethanol (6.9\%) and 1-propanol (3.6\%). The production rate of methane, from which is harmful to separate ethylene, was suppressed to one fifteenth of that of ethylene. In contrast to a thermally-oxidized copper-oxide layer, the doped-carbon and a high ratio of $\mathrm{Cu}_{2} \mathrm{O}$ to $\mathrm{CuO}$ in the devised electrocatalyst may result in the higher productivity and selectivity.
\end{abstract}

Key Words : Eletrocatalytic $\mathrm{CO}_{2}$ Reduction, Organic Synthesis, Electrochemistry, Interfacial Phenomena, Surface Improvement, Carbon-Doped Copper Oxide

\section{1. 緒言}

地球温暖化を抑制するためには大気中の二酸化炭素濃度の低減が効果的である. クリーン開発メカニズム (CDM)などで開発途上国への経済支援により二酸化炭素の排出を抑制することもできるが, 効率的な二酸化炭素 固定化技術が開発されれば，地球規模での二酸化炭素濃度削減に貢献できる.

大気中の二酸化炭素の固定化には，植林などの生物学的固定法や，地中や海中貯留などの物理学的固定法があ る ${ }^{(1)}$ が, 本研究では触媒を利用した電気化学反応による原料化を提案する. 二酸化炭素は化学的に安定であるた め, 原料化が実用に供されるためには, 安価なコストで付加価值が高い原料が選択的に得られる必要がある. 付 加価值が高い工業原料としてはエチレンやプロパノールが候補となる.さらに使用する電力を含めて二酸化炭素 の排出量が有機合成に使用される量よりも十分に小さいことが必須である.

本研究の目的は, 常温・常圧下で二酸化炭素からエチレンやプロパノールなどの工業原料を選択的かつ高効率 に有機合成できる触媒を開発することである.

\section{2. 触媒形成法}

著者らは, チタンの表面を炭化と酸化を同時に進行させ, カーボンドープ酸化チタンに表面改質するフレッシュ グリーン $(\mathrm{FG})$ 技術を開発した ${ }^{(2)}$. 表面改質層は可視光応答型光触媒として高い量子効率が得られ，さらに硬度や 耐摩耗性にも優れる(2). また原子炉被覆管であるジルコニウム合金や制御棒であるハフニウム合金にも適用でき, 耐食性や耐水素吸収性を向上させることができる(3).

二酸化炭素の電気化学還元は過去にもさまざまな元素を電極として実験が進められてきた. 表 1 に還元電極と して用いられた元素と主生成物を分類して示す ${ }^{(4)}$. 表中の多くの元素では二酸化炭素が還元されず，水分解によ

\footnotetext{
* 原稿受付 2012 年 8 月 15 日

*1 正員, 一般財団法人 電力中央研究所（一201-8511 東京都狛江市岩戸北 2-11-1）

E-mail: furuya@criepi.denken.or.jp
} 
Table 1 Periodic table of pure elements, which are classified by main products from Electrocatalytic $\mathrm{CO}_{2}$ reduction at atmospheric temperature and pressure ${ }^{(4)}$.
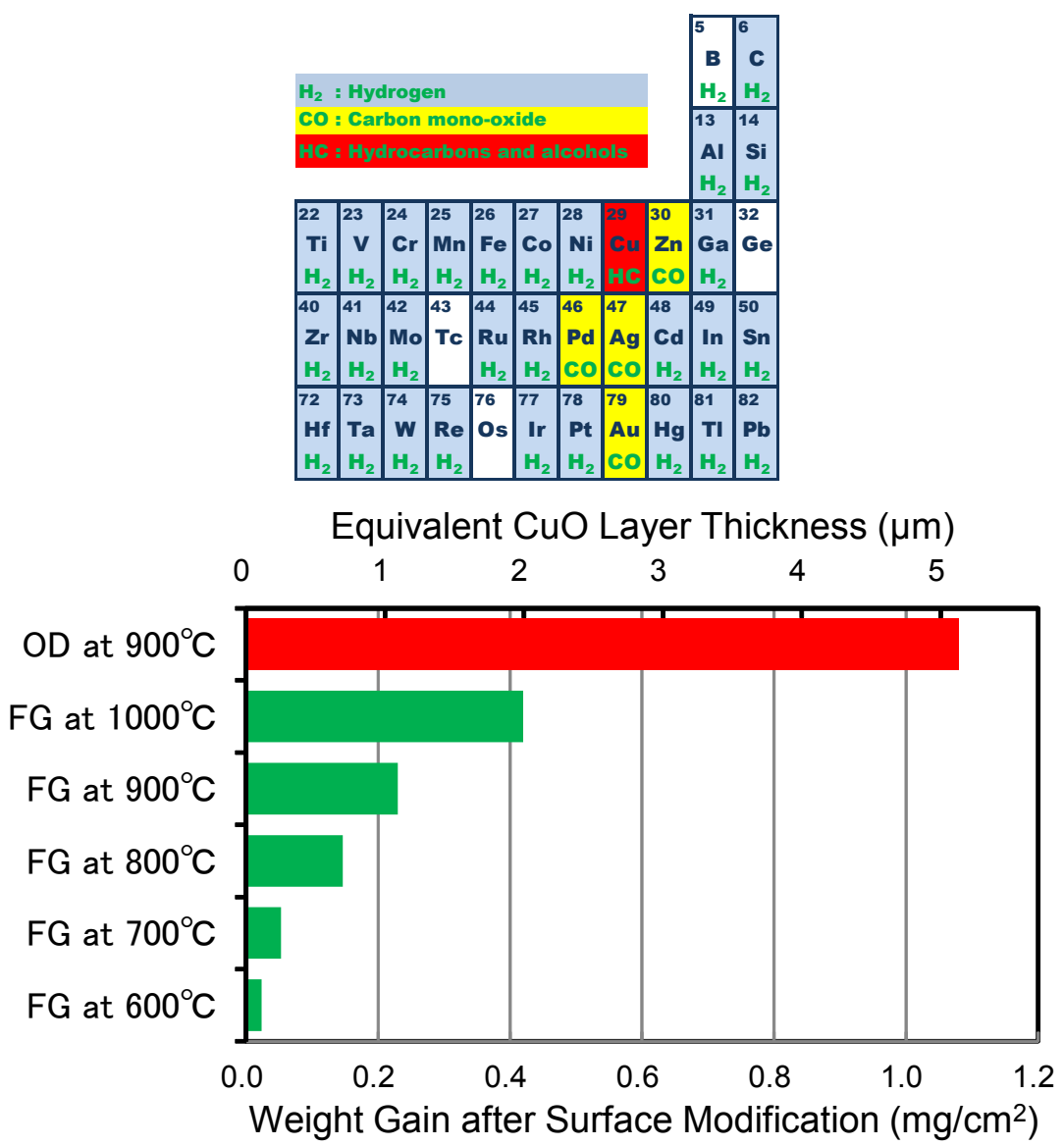

Fig.1 Weight gain after Fresh Green (FG) and Air Oxidation (OD) surface modification

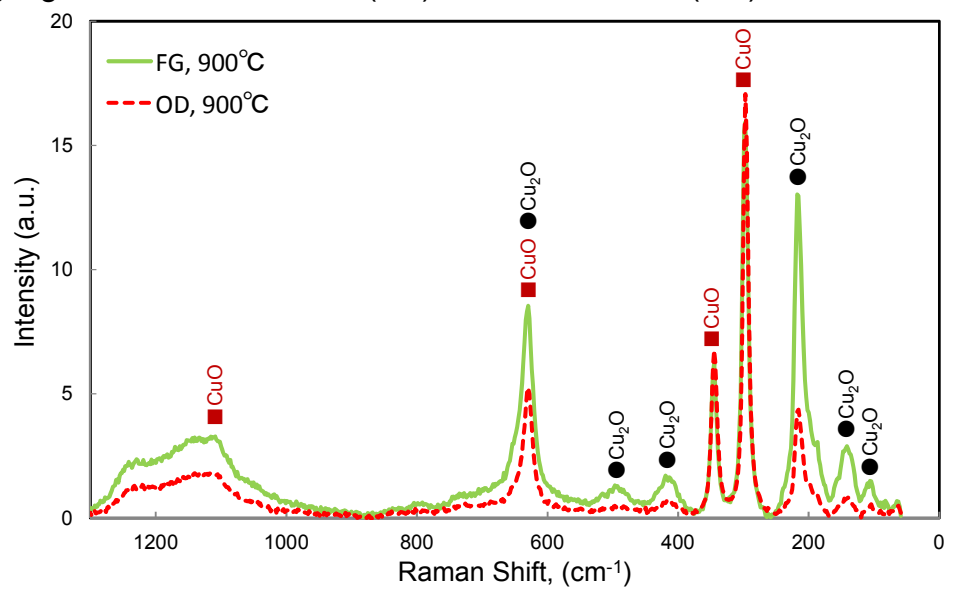

Fig.2 Raman spectra of modified copper-oxide layer

り水素が生成している. $\mathrm{Cu}$ に化学的性質が似ている $\mathrm{Zn}, \mathrm{Pd}, \mathrm{Ag}$ および $\mathrm{Au}$ では CO が生成する. 有望な元素は $\mathrm{Cu}$ であり，炭化水素（主にメタン）やアルコール（主にメタノール）の生成が確認されている．本研究では，より 付加価值の高いエチレンやプロパノールなどの生成を目指すことから, 基材に Cu を選定し, 前述の FG 処理を適 用してカーボンドープ酸化銅を表面に形成させた。酸素分圧が極めて低く，カーボンポテンシャルが高い雰囲気

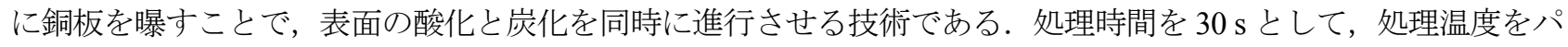
ラメータに $600{ }^{\circ} \mathrm{C}$ から $100{ }^{\circ} \mathrm{C}$ 毎に $1000{ }^{\circ} \mathrm{C}$ ま゙の 5 水準で $\mathrm{FG}$ 処理した.

図 1 に FG 処理温度と処理重量増を示す. 温度上昇に伴い, 処理後の重量が増加している. FG 皮膜は $\mathrm{CuO} と$ $\mathrm{Cu}_{2} \mathrm{O}$ の混合物であるが, 仮に皮膜が全て $\mathrm{CuO}$ として試算した膜厚を図 1 上部に記載した. 例えば $\mathrm{FG}$ 処理 $900{ }^{\circ} \mathrm{C}$, 
$30 \mathrm{~s}$ で約 $1.1 \mu \mathrm{m}$ の厚さになる. 比較のため, 大気中酸化(OD)処理で表面を酸化させた場合を図 1 に示す.同じ処 理温度 $900{ }^{\circ} \mathrm{C}$ で比較すると, FG 処理は酸素分圧が著しく低い雾囲気で処理するため, OD 処理の $1 / 5$ の重量増と なっている. なお, OD 処理では時間と共に重量増は単調増加し, 長時間処理では酸化膜が剥離した. FG 処理を 最長 $3600 \mathrm{~s}$ まで実施した結果，OD 処理とは大きく異なり，30 $\mathrm{s}$ 以上では重量も外観も変化が無く，いずれも緻 密な膜が形成された.

図 2 に $900{ }^{\circ} \mathrm{C}$ で FG 処理と OD 処理した銅表面改質皮膜のラマン分光分析結果を示す. ラマン分光分析器は堀 場製作所製 LabRAM HR-800 を用い，波長 $633 \mathrm{~nm}$ のレーザー光で観察した。いずれも図中に記した $\mathrm{Cu}_{2} \mathrm{O}$ と $\mathrm{CuO}$ に起因するラマンシフト位置で大きなピークが観測されている． $\mathrm{CuO}$ の強度は両者で一致するが， $\mathrm{Cu}_{2} \mathrm{O}$ の強度 は FG 処理材は OD 処理材の 2 倍以上である. 結晶構造に特徵的な主ピーク $216 \mathrm{~cm}^{-1}$ と $298 \mathrm{~cm}^{-1}$ を, それぞれ $\mathrm{Cu}_{2} \mathrm{O}$ と $\mathrm{CuO}$ に帰属させると, 全体に占める $\mathrm{Cu}_{2} \mathrm{O}$ の割合は $\mathrm{FG}$ 処理が $38 \%$, OD 処理が $19 \%$ と求まる. よって $\mathrm{FG}$ 処 理皮膜は $\mathrm{Cu}_{2} \mathrm{O}$ の割合が大きい.

\section{3. 有機合成と分析方法}

電解セルは北斗電工製 HX-108 の 2 室 H 型を使用した. 各 $50 \mathrm{ml}$ の 2 室間はガラス隔膜(G4)で隔てられている.

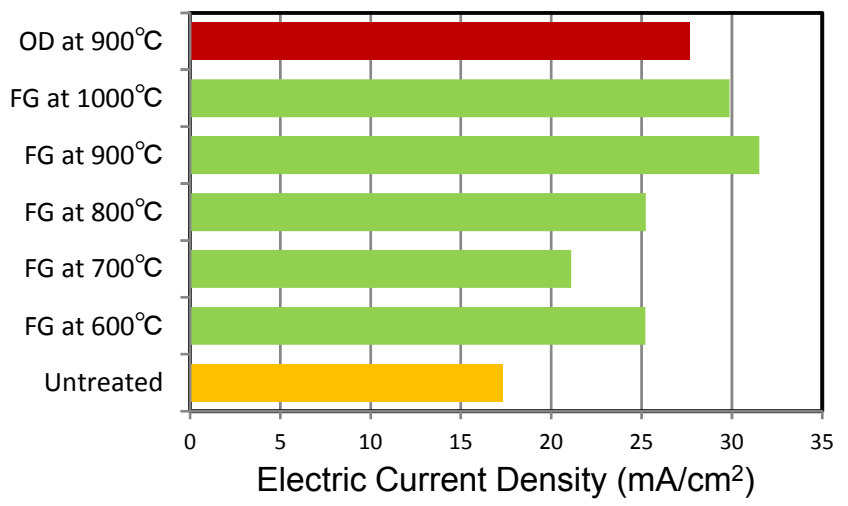

Fig. 3 Cathode current density of modified surface

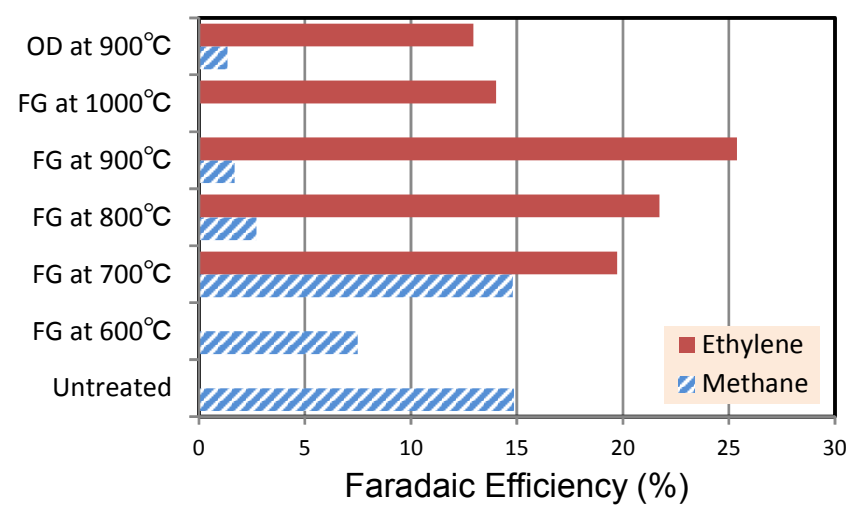

Fig.4 Faradaic efficiency during electrocatalytic $\mathrm{CO}_{2}$ reduction for ethylene and methane

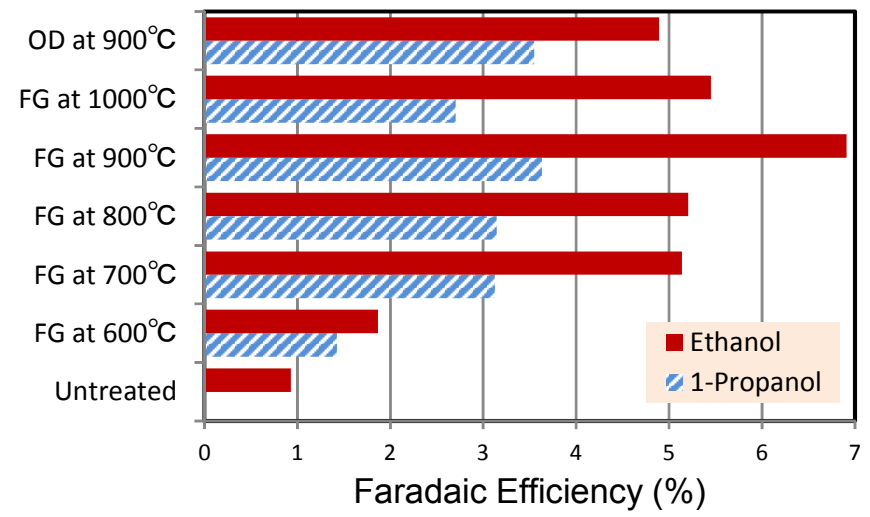

Fig.5 Faradaic efficiency during electrocatalytic $\mathrm{CO}_{2}$ reduction for ethanol and 1-propernol 
参照電極は飽和銀塩化銀電極, 対極には白金板を使用した. 作用極は表面改質した銅板 (ニラコ社製, 純度 $99.99 \%$ ) を $0.25 \mathrm{M} \mathrm{KHCO}_{3}$ 水溶液 $50 \mathrm{ml}$ に旗形状の矩形部分 $\left(15 \mathrm{~mm} \times 10 \mathrm{~mm} \times 0.3 \mathrm{~mm}^{\mathrm{t}}\right)$ を浸漬した. 浸漬面積は約 $300 \mathrm{~mm}^{2}$ である。電解質溶液は二酸化炭素ガスでバブリングした.

電気化学測定器には北斗電工製 HZ-5000 を用いた．作用極は電極電位を約-1.64 V vs SHE に維持した．この值 は試験後に計測した溶液抵抗と液温に基づき補正した值である. 生成物の分析には島津製作所製ガスクロマトグ ラフィ GC-14A を用いた. ガス成分の分析には信和化工製の $6 \mathrm{~m}$ カラム shincarbon ST を用いた. キャリアガスは $\mathrm{Ar}$ ，検出器は TCD である. 試験片通電開始 5 分後と 80 分後にガス流出口に $1 \mathrm{ml}$ シリンジを注入し, 3 回リンス した後に $1 \mathrm{ml}$ を採取し，ガスクロに注入して計測した。液相成分の分析には同社製 $3.1 \mathrm{~m}$ のカラム shincarbon A 60/80を用いた。 キャリアガスは Ar，検出器は FID である. 溶液にシリンジを差し込み $5 \mu \mathrm{l}$ を採取し， 2 回リン スした後に $5 \mu \mathrm{l}$ を採取し，ガスクロにに注入して，10 分毎に 90 分迄計測した.

\section{4. 実験結果および考察}

図 3 に定電位(約-1.64 V vs SHE)を与えて得られるカソード電流を示す. 未処理材(純銅電極)は $17 \mathrm{~mA} / \mathrm{cm}^{2}$ と低 いが，表面改質により電流密度は増大寸る. FG 処理温度が $900{ }^{\circ} \mathrm{C}$ の場合に最も大きな電流密度が得られた。 こ れは同じ温度の大気酸化(OD)処理より大きな電流密度である.

図 4 に気相生成物として 80 分後におけるエチレンとメタンのファラデー効率を示寸. 未処理材や低温 $\left(600{ }^{\circ} \mathrm{C}\right.$, $\left.700{ }^{\circ} \mathrm{C}\right)$ の F 処理材では $10 \%$ 前後のメタンが生成される. $800^{\circ} \mathrm{C}$ 以上の高温ではメタンの生成が抑制されている. メタンは工業原料として有用なエチレンの分離を阻害寸るため, 十分に抑制されることが望ましい. 特に $900{ }^{\circ} \mathrm{C}$ の FG 処理ではエチレンが $25 \%$ 以上生成し,メタンは $1 / 15$ に抑制された. 同じ温度の大気酸化 $(\mathrm{OD})$ 処理では $13 \%$ 程度であることから, FG 処理皮膜ではファラデー効率と電流密度の両指標が OD 処理より 良好である.

図 5 に液相生成物として 90 分後におけるエタノールおよび1-プロパノール(プロパン-1-オール)のファラデー効 率を示寸. 比較のため電流值は 80 分の值を用いて算出した. 10 分ごとに 90 分後まで計測した結果，時間に比例 して液相中の濃度が増大した．従ってファラデー効率は概ね一定であった．いずれの試験片においてもエタノー ルの生成が観測されるが， $900{ }^{\circ} \mathrm{C}$ のG 処理では $6.9 \%$ と最も高い効率が得られた. 1-プロパノールは，未処理材 では得られず，また低温 FG 処理では収率が低い. $900{ }^{\circ} \mathrm{C} の \mathrm{FG}$ 処理では最も高い効率 $3.6 \%$ \%得られた.

\section{5. 結論}

銅板をカーボンポテンシャルが高い雰囲気中で $600{ }^{\circ} \mathrm{C} \sim 1000{ }^{\circ} \mathrm{C}$ に維持することで表面をカーボンドープ酸 化銅に改質した. $\mathrm{CO}_{2}$ バブリングした $0.25 \mathrm{M} \mathrm{KHCO}_{3}$ 水溶液中で電極に定電位(-1.64V vs SHE)を与えた結果，工業 原料として有用なエチレンおよびエタノール，1-プロパノールの生成効率が $900{ }^{\circ} \mathrm{C}$ 処理電極で最大になった. 同 時にエチレン分離を阻害するメタンが $1 / 15$ 以下に抑制されていることから，エチレンが選択的かつ効率的に分離 できる常温・常圧プロセスに利用できると考えられる. 同じ $900{ }^{\circ} \mathrm{C}$ の気酸化処理で形成した酸化銅皮膜より生 成効率が高いことから，ドープしたカーボンや，酸化銅皮膜中の $\mathrm{Cu}_{2} \mathrm{O}$ の組成比が高いことなどが高い選択性と 効率をもたらしたと推察される.

\section{謝 辞}

本研究を遂行する上で(当時)Delft University of Technology $の$ H. Shibata 氏および電力中央研究所 田中伸幸氏に 有益な助言を戴いた。 また電力テクノシステムズ 佐久間勉氏には実験にご尽力いただいた. ここに記し，感謝の 意を表します.

\section{文献}

(1) 牛越憲治, “二酸化炭素の固定化技術”, 神鋼技報, Vol.47, No.3 (1997), pp. 13-17.

(2) M. Furuya, M. Tokiwai et al., "Surface Modification Technology of Titanium, 'Fresh Green' - Durability and Photocatalytic Activity of Carbon-Doped Titanium Dioxide Surface,” Ti-2007 Science and Technology, JIMIC, Vol. 5, No. II (2007), pp. $1727-1730$. 
(3) M. Furuya, S. Kitajima et al., "Surface Modification Technology, Fresh Green to Mitigate Corrosion and Hydrogen-Pickup of Fuel Cladding,” Proc. 2011 Water Reactor Fuel Performance, No. T5-026, Chengdu, China, (2011).

(4) Electrochemical Society of Japan, "A Report of Investigation on Electrochemical Fixation of CO2 with Natural Energy as the Energy Source,” NEDO-GET-98 (1998). 